\title{
Osmanlıca Basında Sunulan Hava Durumu
}

\author{
Remzi Çavuş* \\ (ORCID ID: 0000-0002-7078-4707) \\ Makale Gönderim Tarihi \\ 07.06.2019 \\ Makale Kabul Tarihi \\ 26.08.2019
}

\section{Özet}

1868 yılında Aristide Coumbary tarafından İstanbul'da kurulan rasathane, Birinci Dünya Savaşı́nın sonlarına kadar çalışmışır. Avrupa'dan ithal edilen araç gereçlerle donatılan rasathane, telgraf hatları vasıtasıyla Osmanlı Imparatorluğundaki istasyonlarla ve Avrupa'daki rasathanelerle bilgi paylaşımında bulunmuştur. Böylece istasyonların yaptığı ölçümler, Avrupa'daki rasathanelerden alınan verilerle birlikte değerlendirilmiş ve hava tahmin raporları çıkarılmışır. Elde edilen meteorolojik raporlar, telgraflar ve gazeteler aracılığıyla günlük olarak yayınlanmaya çalışılmıştır. Dönemin imkânları kıııtıdır ve bu nedenle yeterli başarı elde edilememiştir. Rasathane, elde ettiği verileri 1868 yılından başlamak üzere günlük, aylık ve yıllık tablolar halinde düzenlemiştir. Bu verileri halkın istifadesi için basın ile paylaşmıştır. Değişik nedenlerle rasathane çalışmalarının kesintiye uğraması, 31 Mart Olayı'nda Rasathane malzemesinin kısmen tahrip edilmesi ve gazetelerin değişken ilgisi gibi sebepler nedeniyle hava durumu tahminlerinin düzenli olarak yayınlandığı söylenemez.

Anahtar Kelimeler: Hava Durumu, Meteoroloji, Rasathane-i Amire, Osmanlı İmparatorluğu, Osmanlı basını.

\section{Weather Forecast Presented in Ottoman Press}

\section{Abstract}

The observatory that founded by Aristide Coumbary in 1868 in Istanbul, operated until the end of the First World War. The observatory that equipped with imported equipment from Europe, has shared information with stations in Ottoman Empire and observatories in Europe countries through telegraph lines. Thus, the measurements made by the stations were evaluated together with the data from observations in Europe and weather forecast reports were

\footnotetext{
*Dr., remzicavus@hotmail.com.
}

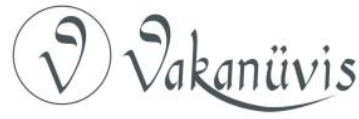


issued. Obtained meteorological reports have been tried to be publicized daily through telegrams and newspapers. The possibilities of the process are limited and therefore, sufficient success has not been achieved. The observatory has arranged the data obtained as daily, monthly and annual tables to start from 1868.The data has been shared with the press for the benefit of the people. It can not be said that weather forecasts are published regularly due to reasons such as the interruption of observatory work for various reasons, the partial destruction of the observatory's material during the March 31 Incident and the variable interest of the newspapers.

Keywords: weather forecast, meteorology, Imperial Observatory, Ottoman Empire, Ottoman press.

\section{Giriş}

Meteorolojik çalışmalar yapmak amacıyla Rasathâne-i Âmire, gerekli alet ve edevat Avrupa'dan getirilerek, Maarif Nezareti'ne bağlı olarak1868 yılında Aristide Coumbary (1826-1896) ${ }^{1}$ tarafından İstanbul'da Beyoğlu'nda kurulmuştur. ${ }^{2}$

Müdürlüğünü 1868'den 1896 yılına kadar A. Coumbary, 1896'ten 1909'e kadar Salih Zeki (1864-1921) yapmıştır. Salih Zeki'nin Maarif Meclisi üyeliğine atanmasından sonra, Fatin Gökmen müdür tayin edilene kadar rasathane müdürlüğü boş kalmıştır. Fatin Gökmen (18771955 ) ise 21 Haziran 1910'dan 1943'e kadar görevde kalmıştır. ${ }^{3}$

Rasathanenin kalabalık bir ekibi olmamıştır. Genel itibariyle bir müdür, bir kâtip ve bir memurdan ibarettir. ${ }^{4}$ Taşradaki telgrafhaneler ve

\footnotetext{
${ }^{1}$ Feza Günergun, “Salih Zeki ve Astronomi: Rasathane-i Amire Müdürlüğü’nden 1914 Tam Güneş Tutulmasına”, Osmanlı Bilimi Araştırmaları, VII/1 (2005), 98; Sevtap Kadıoğlu, Osmanlı'dan Cumhuriyet'e Meteorolojinin Kurumsallaşması ve Ahmet Tevfik Göymen, Ankara Matbaa, İstanbul, 2012, s. 20.

2 BOA. A.\}MKT.MHM, 414/24. 29 Rebiülevvel 1285 (20 Temmuz 1868); Devlet-i Aliye Salnâmesi, (1293), 606-609; Muammer Dizer, Kandilli Rasathanesi, Kandilli Rasathanesi Yayınları, İstanbul, 1973, s. 10; Mithat Atabay, "İstanbul'un Hava Koşullarının Ölçülmesi Kurulan Rasathaneler", İstanbul Araştırmaları Yıllığı, 5 (2016), s. 3.

3 Dizer, a.g.e., 14; Salim Aydüz, "Osmanlı Astronomi Müesseseleri", Türkiye Araştırmaları Literatürü Dergisi, c. 2, S. 4, s. 447, 448.

${ }^{4}$ Günergun, a.g.m., s. 97. Salnâme-i Devlet-i Aliye-i Osmaniye, Selanik Matbaası, Dersaadet, 1326, s. 334; Salnâme-i Devlet-i Aliye-i Osmaniye, Selanik Matbaası, Dersaadet, 1327; Salnâme-i Devlet-i Aliye-i Osmaniye, Matbaa-i Âmire, Dersaadet, 1311, s. 406;
}

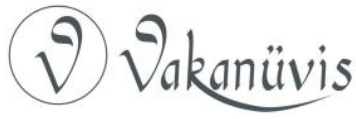


bazı okullar istasyon vazifesi gördüğünden, memur istihdam etmeye gerek duyulmamıştır. ${ }^{5}$

Salih Zeki'nin rasathaneden ayrılmasından sonra burada kâtip olarak vazife yapmakta olan Bediî Bey, rasathaneyi Beyoğlu'ndaki binadan Maçka'daki topçu kışlasının karşısına, telgrafhanenin yanına taşımıştır. Böylece taşradan gönderilen veriler hızlı bir şekilde elde edilebilmiştir. Rasathane 31 Mart Olayı'na (13 Nisan 1909) kadar kesintisiz bir şekilde çalışmıştır. 31 Mart Olayı'nda Topçu Kışlası karşısındaki rasathane tahrip edilmiştir. ${ }^{6}$ İsyan esnasında rasathanenin içindeki cihazlar, kütüphanedeki kitaplar ve 1888-1909 dönemine ait tutanaklar kısmen tahrip edilmiştir. Rasathane bu yüzden, İcadiye Tepesi'nde yeniden açıldığı 1 Temmuz 1911 tarihine kadar düzenli bir şekilde meteorolojik ölçümler yapmamıştır. ${ }^{7}$

Rasathanenin uzun bir süre çalışmaması aydın çevrelerde tepkiyle karşılanmıştır. Sırat-ı Müstakim'deki "Mekteplerde Alâim-i Cevviye Rasadhaneleri" başlıklı makalede, Osmanlı ülkesinde meteoroloji çaIışmalarının durumu hakkında değerlendirmeler yapan Edhem Nejad, ${ }^{8}$ Osmanlı ülkesinde bu tür çalışmaların geri olmasını eleştirdikten sonra bir rasathanenin oluşturulması için fazla bir para gerekmediğini dile getirdikten sonra o dönemin şartlarında rasathane için gerekli olan tüm cihazların, en kalitelisinden olmak şartıyla, 4000 kuruşa mal oldu-

Salnâme-i Devlet-i Aliye-i Osmaniye 1321 Hirci, Dersaadet, 1319, s. 423; Salnâme-i Devlet-i Aliye-i Osmaniye 1323 Hicri, Dersaadet, 1321, s. 484.

51868 yılı Ağustos-Kasım dönemi gözlem defterinde mevcut istasyon adları şu şekilde verilmiştir: İstanbul, Soulina, Köstence, Varna, Burgaz, Trabzon, Rodos, Çanakkale, Kavala, Selanik, Manastır, Valana, Elbasan, Durazzo, Beyrut. Aslında bunlar tam teşekküllü birer meteoroloji istasyonu değildir. Çünkü o dönemde, elde edilen verilerin İstanbul'daki rasathaneye zamanında ulaştırıması için, taşradaki telgrafhaneler meteoroloji istasyonu olarak kullanılmıştır. BOA. A.\}MKT.MHM. 414/24, 29 Rebiülevvel 1285 (20 Temmuz 1868); Devlet-i Aliye Salnâmesi, 1293, s. 606-609; Dizer, a.g.e., s. 10. Kadıoğlu, a.g.e., s. 24.

${ }^{6}$ Aydüz, a.g.m. , s. 447, 448; Kadıoğlu, a.g.e., s. 25.

7 Rasathâne-i Âmire 1912- 1913, 1914 Senelerine Ait, Hulasa-i Rasadâtı, Matbaa-i Âmire, İstanbul, 1330, s. 4; Tanin, nr. 703, 16 Ağustos 1910, s. 3; Aydüz, a.g.m., s. 447, 448. A. Süheyl Ünver, "Tarihimizde İcadiye Tepesi ve Rasadhanesi", Türkiye Turing ve Otomobil Kurumu Belleteni, 240 (1962), s. 7, 8.

${ }^{8}$ Edhem Nejad: 1887 yılında İstanbul'da doğan ve 1921 'de vefat eden; ittihatçı, Türkçü, sosyolog ve eğitimci olan Edhem Nejad, Türkiye Komünist Partisi'nin üyelerinden ve Türkiye'de sosyalist düşüncenin meşhur simalarından biridir.

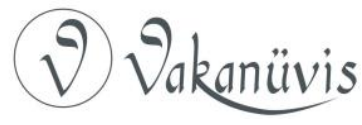


ğunu belirtmiştir. ${ }^{9} 31$ Mart Olayı'ndan sonra rasathanenin uzun bir süre atıl bir şekilde kalması ve faaliyetlerine devam etmemesi Meclis-i Mebusan'ın gündemine de gelmiştir. Meclis-i Mebusan'ın 28 Temmuz 1325 (10 Ağustos 1909) tarihli oturumunda söz alan Maarif Nâzırı Ferit Paşa, rasathanenin mevcut olmadığını ve rasathaneyi o sene içinde kuracaklarını belirtmiştir. Meclis başkanı ise Yıldız Sarayı'ndaki rasathanede ${ }^{10}$ kullanılacak malzemeler olduğunu, bunların kullanılacağını söylemiştir. 29 Mayıs 1326 (11 Haziran 1910) tarihli oturumda söz alan Antalya Mebusu Hamdi Efendi, Avrupa'da büyük bir rasathane için 1.200.000 Frank harcandığını, rasathanenin çalışmasının elzem olduğunu, böyle bir kurumun devletin başka devletler karşısındaki saygınlığı açısından da önemli olduğunu, bütçeye rasathane için yeterli ödenek konulması gerektiğini ifade etmiştir. Ayrıca, en azından 200-300 liraya mal olan bir rasathanenin kurulmasını istemiştir. Hamdi Efendi'den sonra söz alan Maarif Nâzırı Emrullah Bey ise, hava durumunun yıllardır okullar tarafından düzensiz bir şekilde yapılan ölçümlerle tespit edildiğini, deniz taşımacılığı açısından hava raporlarının gerekli olduğunu, isabetli raporlar tutulabilmesi için ülke içinde ölçümlerin mükemmel yapılması gerektiği gibi başka ülkelerin rasathanelerinden alınacak verilerin de kullanılması gerektiğini dile getirmiştir. ${ }^{11}$

1911 yılında, rasathanenin faaliyetlerine aktif bir şekilde devam etmesi için hükümet tarafından gerekli adımlar atılmış ve rasathane masrafı için 1911 yılı bütçe görüşmelerinde 120.000 kuruş olarak kabul

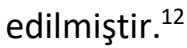

Balkan Savaşı (1912-1913) sırasında, rasathanenin meteoroloji çaIışmalarında aksamalar yaşanmıştır. Rasathâne-i Âmire Müdürü Fatin Gökmen'in verdiği bilgilerden anlaşıldığına göre, Birinci Dünya Savaşı

\footnotetext{
9 Edhem Nejad, "Mekteplerde Alâim-i Cevviye Rasadhaneleri", Sırat-ı Müstakim, 130 (1326), s. 426-428; 1914 yılı temmuz ayında 1 çeki odun, yaklaşık olarak, 45 kuruş, 1 kg zeytinyağı 6 kuruştur.

10 II. Abdülhamit'in emriyle 1884 'te Coumbary tarafından kurulmuştur. Avrupa'dan getirilen teknik araç gereçlerle modern bir rasathane özelliği kazandırılan Yıldız Rasathanesi'nin çalışmaları II. Abdülhamit'in tahttan indirilmesiyle sona ermiştir.

${ }^{11}$ MMZC (Meclis-i Mebusan Zabıt Ceridesi), í. 129. 28 Temmuz 1325; MMZC, i. 110. 29 Mayıs 1326.

12 MMZC, I. 104. 9 Mayıs 1327; Devlet-i Osmaniye 1327 Senesine Mahsus Bütçedir, Matbaa-i Âmire, İstanbul, 1327, s. 65.
}

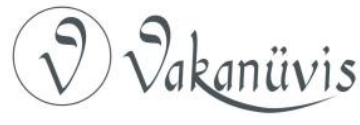


öncesinde, Rusya'nın Karadeniz sahillerindeki ölçüm istasyonlarının sayısı 34'ü bulmuştur. Bu istasyonların yaptığı ölçümler sayesinde Rusya çıkabilecek fırtınalardan önceden haberdar olmuş, denizcilerini uyarmış, dolayısıyla da olabilecek kaza ve zararların önüne geçmiştir. Osmanlı Devleti'nin meteoroloji istasyonları yetersiz olduğundan, ihtiyaç duyulan veriler elde edilememiş dolayısıyla da hava durumuna bağlı deniz kazaları devam etmiştir. ${ }^{13}$

Birinci Dünya Savaşı esnasında Almanların yönlendirmesi ve teknik destekleriyle, savaş uçaklarının hareketlerinin hava şartlarına göre planlanması için, meteoroloji çalışmalarına yeniden ağırlık verilmiştir. Uçakların keşif veya taarruz yapacakları bölgelerin bulutluluk, sis ve yağış durumlarını tam bilmeleri gerekir. Sisin hangi saatte çöküp hangi saatte kalktığı, ne kadar kalınlıkta ve genişlikte olduğu vs. bilinmelidir. ${ }^{14}$ Bunun için Anadolu ve Rumeli'nin muhtelif yerlerine rasâdat-ı havaiye şubeleri (meteorolojik gözlem istasyonları) kurulmuştur. İstanbul (Kuruçeşme, Vaniköy), Edirne, Zonguldak, Sinop, Giresun, Gelibolu, İzmir, Antalya, Adana, Eskişehir, Ankara, Sivas, Konya, Halep, Şam ve Mardin'de birer şube, Filistin Cephesi'nde 5 tali şube kurulmuştur. Şubelerin günlük olarak yaptığı ölçümler telgrafla İstanbul'a bildirilmiştir. ${ }^{15}$

Savaş esnasında hava raporları sadece hava kuvvetleri açısından önemli değildir. Piyade birlikleri ve topçu birliklerinin de hava raporlarına göre hareket etmesi gerekir. Özellikle de top atışları rüzgârın şiddeti ve yönü; hava sıcaklığı dikkate alınarak yapılır. Batarya komutanları günün belirli saatlerinde rasadât-ı havaiye kıtasından ( günümüzde ölçme taburları vardır) hava durumu raporu alır ve bu raporu defterine kaydeder. Tatbikatlarda ve savaşlarda atışlar bu raporlar göz önünde bulundurularak yapılır. ${ }^{16}$ Ayrıca günlük hava durumu harp ceridelerini

\footnotetext{
${ }^{13}$ Dersaadet, nr. 92, 15 Teşrinievvel 1336 / 15 Ekim 1920, s. 1.

${ }^{14}$ Vekayi ve Terakkiyat-ı Havaiye Risalesi, 10 (1334), s. 9; Dersaadet, nr. 94, 17 Teşrinievvel 1336 / 17 Ekim 1920, s. 1. I. Dünya Savaşı'na Almanlar 256, Fransızlar ise 158 uçakla girmiştir. O zamanlar bu uçakların ortalama hızı saatte $115 \mathrm{~km}$ kadardır. Erkan-ı Harbiye Miralayı Muzaffer, Kuva-yı Havaiye Rehberi, Matbaa-i Askeriye, İstanbul, 1926, s. 34.

${ }^{15}$ Dersaadet, nr. 94, 17 Teşrinievvel 1336 / 17 Ekim 1920, s. 1. Kadıŏlu, a.g.e., s. 26, 27.

${ }^{16}$ Topçu Mecmuası, 16, (1926), s. 44.
}

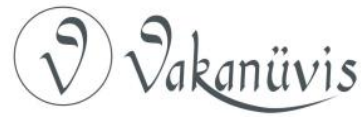


tutan subaylar tarafından yazıya geçirilir. ${ }^{17}$ Birinci Dünya Savaşı'nda Osmanlı ordularının iki taarruz cephesi incelendiğinde, ne Süveyş KanaIı'na doğru 4. Ordu'yu taarruza geçiren Cemal Paşa'nın ne de 9. ve 10. Kolordu'yu Sarıkamış'a doğru yürüten Enver Paşa'nın hava şartlarını dikkate aldığı görülür. Enver Paşa, Hasan İzzet Paşa ve Galip Paşa gibi komutanların hava şartlarıyla ilgili olarak yaptığı tüm uyarıları dikkate almamıştır. Aralık 1914'te başlayan harekât Ocak 1915'te Türk kolordularının perişanlığıyla sonuçlanmıştır. ${ }^{18}$

Mondros Mütarekesi 1918'te imzalandıktan sonra, savaşta kurulmuş olan meteoroloji istasyonları kapatılmış, ölçüm işlerinde kullanılan alet ve edevat Maarif Nezareti'ne bağlı yerel birimlere teslim edilmiş, bu istasyonlarda tecrübe kazanmış olan subaylar ise dağıtılmıştır. 1920 yılında, rasathane çalışmalarının düzenli bir şekilde yürütülmesi için tekrar harekete geçilmiştir. Yeni rasathane şubelerinin teçhiz edilmesi için mütarekeden sonra Maarif Nezareti'ne teslim edilmiş olan alet ve edevat, teknik eleman olarak ise savaşta ölçüm istasyonlarında vazife yapmış olan personelin kullanılması düşünülmüştür. ${ }^{19}$

1920 yılında, Karadeniz ve Marmara'nın değişik noktalarında ve derinliklerinde sıcaklık ve akış durumlarını tespit etmek için Fransa ve Italya'dan bir bilim heyeti gelmiştir. Bu heyete Osmanlı Devleti adına da Rasathâne-i Âmire Müdürü Fatin Bey katılmıştır. Fatin Bey, Dersaadet Gazetesi muhabirine verdiği bilgilerde bu heyetle beraber üç ay boyunca incelemeler yaptığını, çalışmaların en az üç sene de daha devam edeceğini belirtmiştir. Denizdeki gelgit olaylarını ve diğer değişmeleri ölçmek için ise Arnavutköy'de bir istasyon kurulmuştur. ${ }^{20}$

\section{Meteoroloji raporlarının hazırlanması}

1854 yılında çıkan büyük bir fırtına Avrupa ve Karadeniz sahillerini vuran şiddetli fırtınadan Fransa donanması büyük zarar görmüştür. Bu

17 ATASE. BLH. 732/H2/1-69; BLH. 732/H2/1-68; BLH. 734/H4/1-11a; BLH. 734/H4/112; BLH. 734/H5/1-17a; BLH. 734/H/1-12.

18 BOA. DH.ŞFR, 454/21; ATASE. BDH. 139/638/51-4, 5; Selahattin Güngör, Komutanlarımızın Harp Hatıraları, Kanaat Kitabevi, İstanbul, 1937, s. 63, 64; Enver Ziya Karal, Osmanlı Tarihi, c. 9, Türk Tarih Kurumu, Ankara, 1999, s. 420.

${ }^{19}$ Dersaadet, nr. 92, 15 Teşrinievvel 1336 / 15 Ekim 1920, s. 1; Dersaadet, nr. 94, 17 Teşrinievvel 1336 / 17 Ekim 1920, s. 1.

${ }^{20}$ Dersaadet, nr. 92, 15 Teşrinievvel 1336 / 15 Ekim 1920, s. 1.

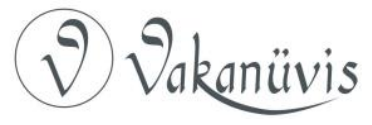


durumdan ders çıkaran Fransa, Paris'teki rasathanenin merkez kabul edilerek dünyanın önemli merkezlerindeki rasathanelerin aralarında, telgraf vasıtasıyla, meteoroloji ölçüm verilerini paylaşmasını teklif etmiştir. Fransa'nın bu teklifi Avrupalı devletler tarafından kabul edilmiştir. Anlaşmayı kabul eden devletlerin rasathaneleri 1863 yılında, Paris Rasathanesi merkez kabul edilmek üzere, veri paylaşmaya başlamıştır. ${ }^{21}$ Ancak, hava tahminlerinin doğru yapılamamasından veya yapılan ihtarların dikkate alınmamasından dolayı, Avrupa ve Anadolu sahillerinde, fırtınaya bağlı deniz kazaları görülmeye devam etmiştir. ${ }^{22}$

Coumbary, Fransa'daki sistemi örnek göstererek bir fırtınanın gelişinin önceden haber alınabilmesi için telgrafhanelerden hava durumu raporu alınması gerektiği fikrini ortaya koymuştur. Bu düşünce doğrultusunda telgrafhanelere hava ölçüm cihazları verilmiştir. ${ }^{23}$ Böylece Trabzon, Kale-i Sultaniye, Selanik, Sakız, İzmir, Beyrut, Bağdat gibi bazı merkezlerdeki telgrafhaneler Rasathâne-i Âmire'nin şubeleri olarak kabul edilmiştir. Bu şubeler, yaptıkları hava ölçümlerini her gün 08.00 'da, telgrafla, İstanbul'daki rasathaneye bildirmiştir. ${ }^{24}$ Zamanla, telgrafhane görevlilerinin bu işi hakkıyla yapamadıkları anlaşılmıştır. Bunun üzerine taşradaki bazı okullara meteorolojik ölçüm cihazları verilerek günlük hava raporları isteme yoluna gidilmiştir. ${ }^{25}$ Ancak bu uygulamadan da beklenen verim elde edilememiştir. ${ }^{26}$ Bu tür olumsuzlukların yaşanmasına taşrada istasyonların kurulmaması ve meteoroloji eğitimi almış kişilerin istihdam edilmemesi sebep olmuştur.

1873'te Viyana'da, Coumbary'nin de katıldığı uluslararası meteoroloji kongresi yapılmıştır. Bundan sonra, kongrede alınan kararlar gereğince, İstanbul'daki rasathane de Avrupa'daki rasathanelerle iletişim halinde olmuş ve veri paylaşmıştır. Rasathane öğleden önce üç ve öğ-

\footnotetext{
${ }^{21}$ Coumbary, Dersaadet Rasathâne-i Âmire'nin Cevv-i Havaya Dair Yirmi Senelik Tarassudatı Neticesi, Dersaadet, 1304, s. 4-6; Devlet-i Aliye Salnâmesi, 1293, s. 606-609.

22 Tercüman-ı Hakikat, nr. 6767-1567, 27 Şubat 1900, s. 3; Dersaadet, nr. 85, 8 Ekim 1920, s. 3; Dersaadet, nr. 85, 8 Ekim 1920, s. 3; Dersaadet, nr. 87, 10 Ekim 1920, s. 3. ${ }^{23}$ Kübra Fettahoğlu, Rasadhane-i Âmire'nin Kuruluşu ve Faaliyetleri, Basılmamış Yüksek Lisans Tezi, İstanbul 2012, s. 4; Hülya Yeşilyaprak, "Kandilli'nin Teleskopları", Türkiye'deki Teleskoplarla Bilim Sempozyumu, s. 62.

${ }^{24}$ Devlet-i Aliye Salnâmesi, 1293, s. 606-609.

25 BOA. MF. MKT, 312/42, 9 Nisan 1312 (21 Nisan 1896).

${ }^{26}$ MMZC. I. 129. 28 Temmuz 1325; MMZC. I. 110. 29 Mayıs 1326.
}

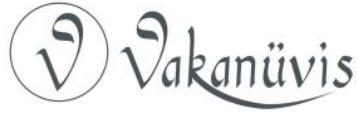


leden sonra üç defa olmak üzere günde altı defa yaptığı ölçümleri deftere kaydetmiştir. Ülke içindeki şubelerden günlük olarak elde edilen sıcaklık, basınç, yağış, nem, rüzgâr durumu defterlere işlenmiştir. Elde dilen raporlar Paris, Roma, Petersburg, Viyana, Odesa, Atina, Sofya, Belgrat gibi önemli merkezlerdeki rasathanelerle paylaşmıştır. Kendisi de aynı merkezlerden hava raporları almıştır. Böylece birkaç gün sonra meydana gelebilecek fırtınalardan ve yağışlardan önceden haberdar olunmuş; raporlar memleket içindeki rasathane şubelerine ve iskelelere bildirilmiştir. ${ }^{27}$ Ancak bu işleyiş düzenli ve istikrarlı bir şekilde devam etmemiştir.

Resmi makamlar arasında yapılan yazışmalardan da anlaşıldığında göre, 1896 yılına gelindiğinde, ülkenin başta gelen şehirlerinde bile düzenli bir şekilde meteorolojik ölçümleri yapacak istasyonlar kurulmuş değildir. Telgraf memurları ve okul müdürlerine havale edilen ölçüm işleri ise düzenli bir şekilde yürümemektedir. ${ }^{28}$

\section{Meteoroloji raporlarının paylaşılması}

Rasathâne-i Âmire kurulmadan önce, Ceride-i Havadis gazetesinde 1841 yıından itibaren hava raporları yayımlanmıştır. Gazete, hava raporunu bazı sayılarında ilk sayfasında, bazılarında ise ikinci sayfasında sunmuştur. Genel itibariyle ise ikinci sayfa kullanılmıştır. Gazete, hava raporlarını hangi kaynaktan aldığını belirtmemiştir. Fakat gazetenin 68 numaralı ve 26 Zilkade 1257 tarihli nüshasının birinci sayfasında, Avrupa'dan İstanbul'a bir bilim adamının geldiğinden ve bu kişinin elindeki cihazlarla 1840 ve 1841 yıllarıyla ilgili olarak hava ölçümleri yaptığından bahsedilmiştir. ${ }^{29}$

27 BOA. MF. MKT. 37/45. 25 Cemaziyülevvel 1293 (18 Haziran 1876); BOA. BEO. 73/5410. 27 Safer 1310 (20 Eylül 1892); Salnâme-i Nezaret-i Maarif-i Umumiye, İstanbul, 1319, s. 63, 64; Devlet-i Aliye Salnâmesi, 1293, s. 606-609; Coumbary, a.g.e., s. 46. Denizcilik yapanların fırtınalara karşı daha bilinçli olması için, onlara verilmek üzere, meteoroloji rehberi hazırlanması yoluna gidilmiştir. BOA. i.DH. 719/50200. 28 Safer 1293 (25 Mart 1876).

28 BOA. MF.MKT. 312/42.

${ }^{29}$ Ceride-i Havadis, nr. 68, 26 Zilkade 1257, s. 1; Ceride-i Havadis, nr. 49, 11 Receb 1257, s. 1; Ceride-i Havadis, nr. 50, 18 Receb 1257, s. 2; Ceride-i Havadis, nr. 51, 25 Receb 1257, s. 1; Ceride-i Havadis, nr. 306, 17 Zilkade 1262, s. 2. 
Teferruatlı ve birkaç gün sonrasının tahminlerini sunan bir hava durumu raporunu düzenleyebilmek için geniş bir sahadaki değişkenlerin ölçülmesi ve elde edilen verilerin paylaşılması gerekir. Bunun için de telgrafa ihtiyaç vardır. 1830 'da icat edilen telgraf Osmanlı ülkesine Kırım Harbi (1853-1856) esnasında girmiştir. Ülke içindeki yerleşimler arasında telgraf ağının oluşturulması ise yıllarca sürmüştür. ${ }^{30}$ Tutarlı $^{2}$ tahminlerin yapılabilmesi için dünyanın başka bölgelerindeki ölçümlerin de bilinmesi gerekmektedir. Avrupa ülkelerindeki rasathaneler arasında veri paylaşımı 1863 senesinde başlarken Osmanlı Devleti bu organizasyona yaklaşık on yıl sonra katılmıştır. ${ }^{31}$ Basiret gazetesinin 24 Mart 1286 tarihli nüshasında, birkaç gün sonra büyük bir fırtınanın olacağının Paris'teki rasathaneden öğrenildiğini ve bu bilginin gerekli birimlere aktarıldığını yazması, Osmanlı gazetelerinin Avrupa'daki rasathanelerden faydalanmasının Viyana'da düzenlenmiş kongreden önce başladığını göstermektedir. ${ }^{32}$

Rasathane-i Âmire, 1868 yılından itibaren, dış merkezlerden ve yurt içindeki şubelerden günlük olarak aldığı sıcaklık, basınç, rutubet, rüzgâr ve yağışla ilgili sayısal bilgileri tablo haline getirerek Yıldız Sarayı'na, İstanbul'daki gazetelere ve iskelelere bildirmiştir La Turqiue, ilk Hava durumu tablosunun ilk yayımlandığı gazete)..$^{33}$ Ancak ìstanbul'daki bütün gazeteler, hava durumu raporlarını düzenli bir şekilde sunmamıştır. Sayfalarında, hava durumuyla ilgili olarak, sadece İstanbul ile ilgili bilgileri paylaşan, dünyadaki önemli merkezleri de kapsayacak şekilde tablolar sunan, Avrupa'daki fırtına ve yağış haberlerini veren gazeteler olduğu gibi hava durumuna hiç yer ayırmayanlar da olmuştur. ${ }^{34}$ Yani i̇stanbul'daki gazeteler hava durumunun sunumu standart-

\footnotetext{
${ }^{30}$ Mustafa Kaçar, Osmanlı Telgraf İ̧̧letmesi, Basılmamış Yüksek Lisans Tezi, İstanbul 1986, s. 73-104.

${ }^{31}$ Salnâme-i Nezaret-i Maarif-i Umumiye, İstanbul, 1319, s. 63, 64; Devlet-i Aliye Salnâmesi, 1293, s. 606-609; Coumbary, a.g.e., s. 4-6.

32 Basiret, nr. 49, 24 Mart 1286, s. 4.

${ }^{33}$ BOA. MF. MKT. 31/77. 13 Şaban 1292 (14 Eylül 1875); Y.PRK.SRN. 2/59; Y.PRK.MF. 3/60; Y.PRK.MF. 4/32; La Turqiue, 1868 ' de ilk defa hava durumu tablosu yayımlayan ve Fransızca olarak çıkan bir gazetedir. Fettahoğlu, a.g.t., s. 52.

${ }^{34}$ Basiret, nr. 188, 11 Ekim 1870, s. 1; Sabah, nr. 3997, 2 Mart 1900, s. 3; ikdam, nr. 715, 16 Temmuz 1896, s. 3; ikdam, nr. 801, 10 Ekim 1896; ikdam, nr. 851, 29 Kasım 1896; Ikdam, nr. 5651, 13 Kasım 1912; Tasvir-i Efkar, nr. 330, 2 Eylül 1286; Tasvir-i Efkar, nr. 363, 22 Kânunusani 1286; Tercüman-ı Hakikat, nr. 10147, 30 Haziran 1905;
}

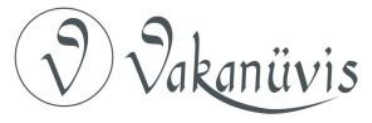


laşmamıştır. Hava durumunu birkaç basit cümleyle geçiştiren gazeteler olduğu gibi İstanbul'un yanı sıra ülke içindeki birkaç merkezin ve Avrupa'daki başkentlerin hava durumunu bildirenler de olmuştur. Mesela, Takvim-i Vekayi'de hava raporunun sunulduğu tabloda İstanbul, Trabzon, Selanik, Beyrut, Bağdat, Basra, Halep, Sakız, Sofya, Paris, Viyana, Petersburg, Moskova, Atina gibi merkezlerin sıcaklık ve yağış durumu verilmiştir. ${ }^{35}$ ikdam gazetesinin 18 Ocak 1897 tarihli nüshasında, hava durumunun teferruatlı bir şekilde sunulduğu çizelgede i̇stanbul, Trabzon, Paris, Viyana gibi merkezlerin sıcaklığı ve basıncı verilmiştir. ${ }^{36}$

31 Mart Olayı sonucunda rasathanenin çalışmaz duruma gelmesi, hava ölçümlerinin yapılmasını aksatmıştır. 1 Temmuz 1911 tarihine kadar düzenli ölçümler yapılmadığı gibi Avrupa'daki merkezlerle de bilgi alışverişi yapılmamıştır. Buna bağı olarak yaklaşık iki sene boyunca İstanbul'daki gazeteler hava durumu sunmamıştır. ${ }^{37}$

1 Temmuz 1911'den itibaren rasathane düzenli bir şekilde ölçüm yapıp bu verileri paylaşsa da tüm gazeteler hava durumu raporunu düzenli bir şekilde sunmamıştır. Sabah gazetesi 14 Eylül 1911 tarihli nüshasında teferruatlı bir şekilde hava durumu raporu verirken Tanin gazetesi, 28 Temmuz 1911 tarihli nüshasında, Servet-i Fünun 21 Kasım 1911 tarihli nüshasında, Takvimli Gazete 5 Ekim 1911 tarihli nüshasında hava raporuna yer vermemiştir. ${ }^{38}$ Yani gazetelerin her biri hava durumu sunmadığı gibi bu iş düzenli de yapılmamıştır.

İstanbul'daki gazetelerde, II. Meşrutiyet Dönemi'ne kadar birkaç gün sonrasında havanın nasıl olabileceğine dair tahminlere pek yer verilmemiştir. Basiret gazetesinin 4 Nisan 1286 tarihli nüshasında, Av-

Tercüman-ı Hakikat, nr. 6767-1567, 27 Şubat 1900, s. 3; Tercüman-ı Hakikat, nr. 10149, 2 Temmuz 1905; Tercüman-ı Hakikat, nr. 10176, 31 Temmuz 1905; Sabah, nr. 6989, 11 Mart 1909; Osmanlı, nr. 16, 1 Nisan 1909; Tanin, nr. 1465, 9 Ekim 1912.

35 Takvim-i Vekayi, nr. 158, 5 Kânunuevvel 1307, s. 2.

36 ikdam, nr. 901, 18 Ocak 1897.

37 Tanin, nr. 274, 7 Haziran 1909; Tanin, nr. 299, 2 Temmuz 1909; ikdam, nr. 299, 2 Temmuz 1909; Tercüman-ı Hakikat, nr. 10147, 30 Haziran 1909; Tercüman-ı Hakikat, nr. 10177, 1 Ağustos 1909; Sabah, nr. 7320, 7 Şubat 1910; Sabah, nr. 7321, 8 Şubat 1910; Sabah, nr. 7343, 2 Mart 1910.

38 Sabah, nr. 7897, 28 Temmuz 1911, s. 4; Tanin, nr. 1043, 28 Temmuz 1911; Servet-i Fünun, nr. 350-51, 21 Kasım 1911; Takvimli Gazete, nr. 1117-1, 5 Ekim 1911; Sabah, nr. 9068, 28 Aralık 1914; Tanin, nr. 2124, 3 Aralık 1914.

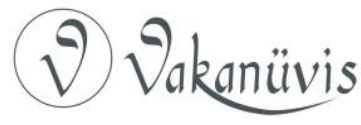


rupa ülkelerinde ileriye yönelik hava tahminlerinin yapılamakta olduğundan övgüyle bahsedilmiştir. ${ }^{39}$ Fatin Bey'in rasathane müdürlüğü yaptığı dönemde İstanbul'daki gazetelerde, birkaç gün sonrasında rüzgârın yönünün ve şiddetinin ne şekilde olacağına ve yağmur yağıp yağmayacağına dair tahminlere yer verilmiştir. ${ }^{40}$

II. Abdülhamit döneminde yapımı tamamlanan Dolmabahçe Saat Kulesi'nin dört tarafına barometre ve termometre takılmıştır. Böylece Beşiktaş civarında hava durumuyla ilgili sayısal bilgiler elde edilmiştir. ${ }^{41}$ Yine II. Abdülhamit döneminde Bâb-ı Âli' de vükelanın toplandığı salona ve sadrazamın makam odasına, içerideki sıcaklığın doktorların tavsiye ettiği seviyede tutulması için, birer termometre takılması kabul edilmiştir. ${ }^{42}$

Rasathane-i Âmire, ölçümlerle elde ettiği verileri değişik tarihlerde istatistikler halinde yayınlanmıştır. Dersaadet Rasathâne-i Âmire'nin Cevv-i Havaya Dair Yirmi Senelik Tarassudatı Neticesi adıyla 1888'de bastırılan kitapçıkta, 1 Ocak 1868'den 31 Aralık 1887'ye kadar olan meteorolojik ölçümler çizelgeler halinde verilmiştir. Bu çizelgelerde ortalama sıcaklık, rüzgârın yönü ve şiddeti; yağış şekli ve miktarı yıllık ve aylık olarak belirtilmiştir. ${ }^{43}$ Rasathâne-i Âmire 1912, 1913, 1914 Senelerine Ait Hulasa-i Rasadâtı adıyla 1914'te basılan kitapçıkta ise 1912, 1913 ve 1914 yılına ait meteorolojik ölçümler yıllık ve aylık olmak üzere çizelgeler halinde sunulmuştur. ${ }^{44}$ istanbul'la ilgili 1913, 1914 ve 1919 yılı meteorolojik ölçümleri Istanbul Beldesi ihsaiyat Mecmuası'nda çizelgeler halinde sunulmuştur. ${ }^{45} 1283$ tarihli Devlet-i Aliyye Salnamesi'nde de İstanbul'un bir yıllık meteorolojik ölçümleri istatistik-

\footnotetext{
${ }^{39}$ Basiret, nr. 57, 4 Nisan 1286, s. 4.

40 Tercüman-ı Hakikat, nr. 12490, 23 Ocak 1916, 2;Tercüman-ı Hakikat, nr. 12504, 7 Şubat 1916, 2; Sabah, nr. 9478, 29 Ocak 1916, s. 1.

${ }^{41}$ Hakkı Acun, Osmanlı Imparatorluğu Saat Kuleleri, Atatürk Kültür Merkezi, Ankara, 2011, s. 44; Çağrı Güntan, II. Abdülhamit Döneminde Imparatorluk Imajının Kamu Yapıları Aracılığı ile Osmanlı Kentine Yansıtılması, Basılmamış Yüksek Lisans Tezi, İstanbul 2007, s. 63.

42 BOA. I.DH. 1261/99031.

${ }^{43}$ Coumbary, a.g.e., s. 9-16.

${ }^{44}$ Rasathâne-i Âmire 1912, 1913, 1914 Senelerine Ait, Hulasa-i Rasadâtı, Matbaa-i Âmire, İstanbul, 1330, s. 10-31.

451330 Senesi Istanbul Belediyesi ihsaiyat Mecmuası (1331), s. 2-9; 1335 Senesi istanbul Belediyesi ihsaiyat Mecmuası (1337), s. 3.
}

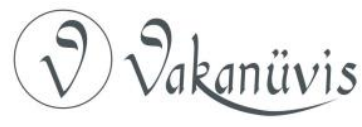


sel olarak sunulmuştur. Bu raporda yıl içinde hangi yönden kaç defa rüzgâr estiğinden aylık sıcaklık ortalamalarına kadar teferruatlı bir şekilde bilgi verilmiş, ayrıca hangi rüzgârın yağış getirip getirmediği de açıklanmıştır. ${ }^{46}$ Dr. Ludwig Friedrich Weickmann (1882-1961) tarafından yazılan Şarkî Bahr-i Sefid Havalisinde Tazyik-i Nesimî ve Rüzgârlar adlı kitapçıkta 1916, 1917, 1918 yıllarının hava durumuyla ilgili istatistikler verilmiştir. ${ }^{47}$ İstatistiksel olarak bir veya birkaç yıllık meteorolojik ölçümlerin çizelgeler halinde verilmesi yabancı basında i̇stanbul basınından daha önce görülmektedir. Mesela İngiltere'de yayımlanan Carlisle Journal adlı gazete 14 Ocak 1843 tarihli nüshasında 1841 ve 1842 yıllarının ay ay yağan yağmur miktarı, karlı gün sayısı, rüzgârlı gün sayısı, ortalama sıcaklığı, en düşük ve en yüksek sıcaklığı, ortalama basıncı tablolar halinde sunulmuştur. ${ }^{48}$

Rasathâne-i Âmire'nin yayınlamış olduğu salnamede hava durumuyla ilgili ölçümlere yer verilmemiştir. Bu salnamede astronomik bilgilere, rüzgârların hızı ve yönüyle ilgili bilimsel açıklamalara, yerel saatin tespit edilmesinde dikkat edilecek hususlara ve bir yıllık yerel saat listelerine yer verilmiştir. ${ }^{49}$

31 Mart Olayı esnasında rasathanedeki tutanaklar tahrip edildiğinden 1888-1909 dönemiyle ilgili yaklaşık yirmi yıllık meteorolojik veriler toplu bir şekilde, çizelgeler halinde halkın hizmetine sunulamamıştır. Bu dönemle ilgili veriler, dönemin gazetelerinden derlenerek istatistiksel tablolara dönüştürülebilir. Fakat ilgili dönemin gazetelerinde de hava durumu düzenli bir şekilde verilmemiştir. Mesela ikdam gazetesi Selanik, Mekke, Trabzon gibi yerleşimlerin hava durumunu sunduğu gibi Viyana, Paris, Moskova gibi dış merkezlerin hava durumunu da tablo halinde sunmuştur. Fakat ikdam, bu işi düzenli olarak yapmamıştır. Hava durumu, gazetenin bazı sayılarında tablo halinde teferruatlı

\footnotetext{
46 Devlet-i Aliye Salnâmesi, 1293, s. 606-609.

47 Ludwig Friedrich Weickmann, Şarkî Bahr-i Sefid Havalisinde Tazyik-i Nesimî ve Rüzgârlar, Çev. Tevfik Ali, İstanbul, 1341.

${ }^{48}$ Carlisle Journal, 4 Ocak 1843, s. 2.

${ }^{49}$ Rasadhâne-i Âmirenin Salnâmesi, Rasadhâne Idaresi, İstanbul, 1288.
} 
bir şekilde sunulurken bazı sayılarında hava raporlarına yer verilmemiştir. ${ }^{50}$

Hava durumu sunmada yabancı gazetelerde de bir uyum olmamıştır. Mesela Standart Journal hava durumu raporunu küçük bir paragrafta birkaç cümleyle geçiştirmiştir. Sheffield Daily Telegraph, sıradan bir haber gibi, paragraf haline getirerek sunmuştur. ${ }^{51}$ The Scotsman, bir gün öncesinin hava durumunu öğleden önce ve öğleden sonra olmak üzere ikiye bölerek bir çizelge halinde vermiş, The Star, haftalık raporlar sunmuş ve bu raporlarında bir hafta öncesinin sıcaklık, yağış ve basınç durumlarını gün gün sunmuştur. London Standard, çizelge halinde sunduğu raporun altına bir paragraflık anlatım eklemiş ve bazı nüshalarında dış merkezlerin hava durumunu da belirtmiş; The Times ise 1877 yılındaki sayılarında İngiltere'nin hava durumunu üzerinde izoterm çizgileri ve rüzgârların yönlerini gösteren oklar gösteren bir harita üzerinden anlatmıştır. Sunmuş olduğu haritaya ilaveten birkaç paragraflık anlatım yaptıktan sonra birkaç gün sonraki hava tahminlerini de sunmuştur. ${ }^{52}$ The Scotsman ise 8 Ekim 1908 tarihli sayısında hava durumuna sütunlarından birini ayırmış; İngiltere'deki hava durumuna yer verdiği gibi Almanya, Fransa, Danimarka, İsveç gibi Avrupa ülkelerinin hava durumuyla ilgili veriler de sunmuştur. Hava durumuyla ilgili olarak yaptığı tahminlerde nem durumundan denizlerdeki duruma kadar bilgiler vermiş ve ayrıca geçmiş ayların ortalamalarını gösteren küçük bir tablo sunmuştur. ${ }^{53}$

Avrupa'daki gazetelerin hava durumuyla ilgili haberleri haritalar kullanarak aktarmaları, farklı ülkelerin hava durumlarına da yer vermeleri Tasvir-i Efkâr tarafından takdirle karşılanmış ve benzer uygulamaların Osmanlı ülkesinde de olması için temenni de bulunulmuştur. ${ }^{54}$

\footnotetext{
50 ikdam, nr.14, 15 Ağustos 1894, s. 4; ikdam, nr. 24, 25 Ağustos 1894, s. 4; ikdam, nr. 40, 10 Eylül 1894; ikdam, nr. 51, 21 Eylül 1894, s. 4.

51 Sheffield Daily Telegraph, 6 Ağustos 1912, s. 6.

52 The Star, 6 Ocak 1864, s. 1; Standart Journal, 4 Ocak 1872, s. 2; The Times, 20 Kasım 1877, s. 6; The Times, 21 Kasım 1877, s. 7; The Times, 23 Kasım 1877, s. 6; The Scotsman, 1 Ekim 1901, s. 3; Southern Echo, 14 Ekim 1901, s. 3; Dunde, Perth, and Cupar Advertiser, 1 Mart 1850, s. 3; London Standard, 17 Aralık 1877, s. 6; London Standard, 18 Aralık 1877, s. 6.

53 The Scotsman, 8 Ekim 1908.

${ }^{54}$ Tasvir-i Efkar, nr. 893, 25 Ekim 1913, s. 3, 4.
}

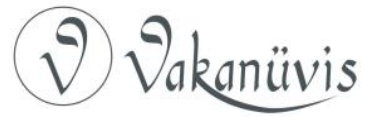




\section{Taşrada hava durumu raporlarının paylaşılması}

Tarımla ilgilenen, hava durumunu takip etmek zorunda kalan fakat günlük gazeteleri takip etmekten mahrum olan kırsal kesim insanları, genel itibariyle, insanlığın uzun sürede edindiği tecrübelere ve gözlemlere dayanan, yılın hangi vaktinde hangi iklimsel olayların olacağını gösteren halk takvimine göre hareket etmiştir. Çünkü halk, yazılı bir şekli olmayan ve nesilden nesle aktarılarak gelen bu takvime uymadığında zarar gördüğünü tecrübe etmiştir. ${ }^{55}$ Salnamelerde sunulan yıllık takvim çizelgesinde de, halk takvimiyle paralel bir şekilde yılın hangi gününde hangi iklimsel olayın olacağı gösterilmiştir. ${ }^{56}$

İnsanlar yüzlerce yıl hayvanların ve bitkilerin durumuna göre meteorolojik tahminlerde bulunmaya çalışmıştır. ${ }^{57}$ Çünkü hayvanlar, havadaki basınç ve nem oranının değişimine ve diğer iklimsel sinyallere karşı daha duyarlıdırlar. Tarım bölgelerinde, kırsalda yaşayan halk, kırlangıçların yüksekten uçmasından, arıların sabah erkenden kovanlarından ayrılarak uzaklara uçmasından, örümceklerin ağ örmeye devam etmesinden havanın iyi olacağı yorumunu çıkarmıştır. Sineklerin insanlara fazlaca musallat olmasından, arıların kovanların etrafından uzaklaşmamasından, örümceklerin faaliyet göstermemesinden ve kırlangıçların alçaktan uçmasından ise yağmur yağacağı yorumu çıkarılmıştır. ${ }^{58}$

Osmanlı ülkesinin Selanik, Trabzon, Bağdat gibi bazı vilayetlerinde meteorolojik ölçümler yapılmıştır. Bu ölçümleri yapan ise telgrafhaneler olmuştur. Yerleşim yerlerinin genelinde ise ölçümler yapılmamıştır. Dolayısıyla da taşradaki yerleşimlerin çoğuyla ilgili hava durumu raporu çıkarılmamıştır. İstanbul'daki gazetelerde Selanik, Bağdat, Trabzon, Sofya gibi bazı vilayetlerin hava durumları sunulmuş, taşradaki gazetelerde ise genel itibariyle hava raporları verilmemiştir. Taşradaki yerel gazeteler genel itibariyle, yağışlardan, fırtınalardan, sellerden, aşırı

\footnotetext{
55 ibrahim Güner ve Oğuz Şimşek, "Iğdır'da Halk Takvimi ve Halk Meteorolojisi”, Türk Coğrafya Dergisi, 33 (1998), s. 131; Nergis Biray, "Bugün Hava Nasıl Olacak?”, Ankara Üniversitesi Dil ve Tarih-Coğrafya Fakültesi Türkoloji Dergisi, 20 (2013), s. 2.

561322 Sene-i Hicriyesine Mahsus Trabzon Vilayeti Salnamesi, s. 2-13; ilmiye Salnamesi, Matbaa-i Âmire, İstanbul, 1334, s. 6-17; Takvim-i Sâl, ỉbrahim Efendi Matbaası, İstanbul, 1312; Takvim ve Hayriye Salnâmesi, Orhaniye Matbaası, Dersaadet, 1921. ${ }^{57}$ Fazıl Nazmi, "Yunan-ı Kadim ve Eski Roma'da Takvim-i Sâl ve Usul-ı Tevarih", Darülfünun Edebiyat Fakültesi Mecmuası, 3-4 (1341), s. 147.

${ }^{58}$ Ahmet Tevfik, Ziraî Meteoroloji, Cumhuriyet Matbaası, İstanbul, 1340, s. 200-202.
}

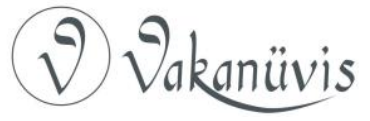


yağan yağmur veya kardan bahsetmiştir. Meteorolojik ölçümlere yer verilmemiştir. ${ }^{59}$

\section{Sonuç}

Meteorolojik çalışmalar sonucunda elde edilen verilerin faydaya dönüştürülmesi etkili bir iletişim ağının kurulmasıyla yakından ilgilidir. Insanoğlunun değişik merkezler arasında hızlı iletişim kurmasını sağlayan ilk araç olan telgraf, XIX. yüzyılın ikinci çeyreğinde kullanılmaya başlamıştır. Osmanlı ülkesinde ise telgrafın kullanılmaya başlaması Kırım Savaşı yıllarında olmuştur. Fakat telgraf hatlarının Avrupa'daki ve Osmanlı ülkesindeki önemli merkezlere çekilmesi yıllarca sürmüştür. Meteoroloji çalışmalarında telgraftan etkin bir şekilde faydalanma ise XIX. yüzyılın sonlarını bulmuştur.

Osmanlı Devleti, Avrupa'da meteoroloji alanında meydana gelen teknik gelişmeleri yakından takip etmek istemiş ve bu alanla ilgili araç gereçleri ithal ederek modern bir rasathane oluşturmaya gayret etmiştir. Fakat ülke içinde, meteoroloji çalışmalarının verimli bir şekilde yürütülmesi için yeterli nitelikte istasyon kurulmamış, meteorolojik ölçüm yapacak yeterli sayıda teknisyen yetiştirilememiştir.. Dolayısıyla da İstanbul'daki rasathane ülke içindeki farklı noktalardaki iklim verilerini etkin bir şekilde elde edememiştir. Ayrıca iç ve dış politikada meydana gelen değişikliklere bağlı olarak, dış merkezlerdeki meteoroloji istasyonlarıyla veri paylaşımı da istendik seviyede olmamış hatta rasathanenin çalışmalarının yıllarca aksadığı olmuştur.

Meteorolojik verilerin gazetelerin aracılığı ile halka duyurulmasında pek başarılı olunamamıştır. XIX. yüzyılın sonu ve XX. yüzyılın başında, İstanbul'daki rasathanenin oluşturduğu raporlar, halkın istifadesine telgraf ve gazeteler vasıtasıyla 1968 yılından itibaren sunulmaya çalı-

Manastır, nr. 1124, 20 Mart 1907, s. 3; Manastır, nr. 1125, 27 Mart 1907, s. 3; Manastır, nr. 1127, 10 Nisan 1907, s. 2; Manastır, nr. 1130, 1 Mayıs 1907; Aks-i Sadâ (Samsun), nr. 274, 9 Teşrinievvel 1326; Aks-i Sadâ (Samsun), nr. 165, 2 Şubat 1325; Bursa (Bursa), nr. 48, 17 Teşrinievvel 1307; Ceride (Edirne), nr. 49, 24 Şubat 1306; Ceride (Edirne), nr. 38, 17 Kânunusani 1306; Sada-yı Şarkî (Erzurum), nr. 7, 7 Ağustos 1911, Sada-yı Şarkî (Erzurum), nr. 10, 28 Ağustos 1911; Ferda (Adana), nr. 4, 3 Ekim 1918; Babalık (Konya), nr. 303, 22 Temmuz 1915; Babalık (Konya), nr. 341, 27 Temmuz 1916; Sivas (Sivas), nr. 3, 7 Nisan 1879; ikbal (Trabzon), nr. 356, 12 Teşrinisani 1329; Asır (Selanik), nr. 1155, 21 Şubat 1907; Asır (Selanik), nr. 10, 29 Nisan 1873.

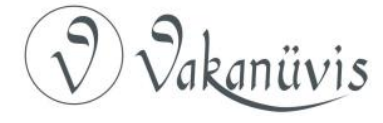


şılmıştır. Fakat bu iş düzenli bir şekilde yapılmamıştır. O günlerde ìstanbul'da günlük olarak basılan gazeteler olsa da taşradaki şehirlerin çoğunda düzenli olarak gazete çıkmamıştır. Günlük olarak çıkarılan gazetelerde bile hava durumu raporları düzenli bir şekilde verilmemiştir.

\section{Kaynakça}

\section{Arşiv Kaynakları}

ATASE. BDH. 139/638/51-4, 5.

ATASE. BLH. 732/H2/1-69.

ATASE. BLH. 732/H2/1-68.

ATASE. BLH. 734/H4/1-11a.

ATASE. BLH. 734/H4/1-12.

ATASE. BLH. 734/H5/1-17a.

ATASE. BLH. 734/H/1-12.

BOA. A.\}MKT.MHM. 414/24, 29 Rebiülevvel 1285 (20 Temmuz 1868).

BOA. BEO. 73/5410. 27 Safer 1310 (20 Eylül 1892).

BOA. DH.ŞFR. 454/21.

BOA. I.DH. 1261/99031.

BOA. i.DH. 719/50200. 28 Safer 1293 (25 Mart 1876).

BOA. MF. MKT. 31/77. 13 Şaban 1292 (14 Eylül 1875).

BOA. MF. MKT. 37/45. 25 Cemaziyülevvel 1293 (18 Haziran 1876).

BOA. MF. MKT. 312/42. 9 Nisan 1312 (21 Nisan 1896).

BOA. Y.PRK.MF. $3 / 60$.

BOA. Y.PRK.MF. $4 / 32$.

BOA. Y.PRK.SRN. $2 / 59$.

\section{Gazete ve Dergiler}

1330 Senesi İstanbul Belediyesi ihsaiyat Mecmuası, 1331.

1335 Senesi İstanbul Belediyesi ihsaiyat Mecmuası, 1337.

Aks-i Sadâ, nr. 165, 2 Şubat 1325.

Aks-i Sadâ , nr. 274, 9 Teşrinievvel 1326.

Asır, nr. 1155, 21 Şubat 1907.

Asır, nr. 10, 29 Nisan 1873.

Babalık, nr. 303, 22 Temmuz 1915.

Babalık, nr. 341, 27 Temmuz 1916.

Basiret, nr. 49, 24 Mart 1286.

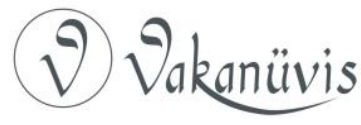


Basiret, nr. 57, 4 Nisan 1286.

Basiret, nr. 188, 11 Ekim 1870.

Bursa, nr. 48, 17 Teşrinievvel 1307.

Carlisle Journal, 4 Ocak 1843.

Ceride, nr. 49, 24 Şubat 1306.

Ceride, nr. 38, 17 Kânunusani 1306.

Ceride-i Havadis, nr. 49, 11 Receb 1257.

Ceride-i Havadis, nr. 50, 18 Receb 1257.

Ceride-i Havadis, nr. 51, 25 Receb 1257.

Ceride-i Havadis, nr. 68, 26 Zilkade 1257.

Ceride-i Havadis, nr. 306, 17 Zilkade 1262.

Dersaadet, nr. 92, 15 Teşrinievvel 1336 / 15 Ekim 1920.

Dersaadet, nr. 94, 17 Teşrinievvel 1336 / 17 Ekim 1920.

Dunde, Perth, and Cupar Advertiser, 1 Mart 1850.

Ferda, nr. 4, 3 Ekim 1918.

ikbal, nr. 356, 12 Teşrinisani 1329.

İkdam, nr. 299, 2 Temmuz 1909.

İdam, nr. 715, 16 Temmuz 1896.

İdam, nr. 801, 10 Ekim 1896.

İkdam, nr. 851, 29 Kasım 1896.

İkdam, nr. 901, 18 Ocak 1897.

London Standard, 17 Aralık 1877.

London Standard, 18 Aralık 1877.

London Standard, 20 Aralık 1877.

Manastır, nr. 1124, 20 Mart 1907.

Manastır, nr. 1125, 27 Mart 1907.

Manastır, nr. 1127, 10 Nisan 1907.

Manastır, nr. 1130, 1 Mayıs 1907.

Osmanlı, nr. 16, 1 Nisan 1909.

Sabah, nr. 299, 28 Haziran 1890.

Sabah, nr. 3997, 2 Mart 1900.

Sabah, nr. 7321, 8 Şubat 1910.

Sabah, nr. 7343, 2 Mart 1910.

Sabah, nr. 7885, 2 Eylül 1911.

Sabah, nr. 7897, 28 Temmuz 1911.

Sada-yı Şarkî (Erzurum), nr. 7, 7 Ağustos 1911.

Sada-yı Şarkî (Erzurum), nr. 10, 28 Ağustos 1911.

Servet-i Fünun, nr. 350-51, 21 Kasım 1911.

Sheffield Daily Telegraph, 6 Ağustos 1912.

Sivas, nr. 3, 7 Nisan 1879.

Southern Echo, 14 Ekim 1901.

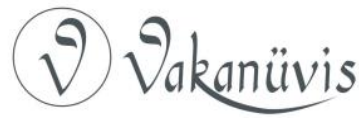


Standart Journal, 4 Ocak 1872.

Takvim-i Vekayi, nr. 158, 5 Kânunuevvel 1307.

Takvimli Gazete, nr. 1117-1, 5 Ekim 1911.

Tanin, nr. 274, 7 Haziran 1909.

Tanin, nr. 299, 2 Temmuz 1909.

Tanin, nr. 1043, 28 Temmuz 1911.

Tanin, nr. 2124, 3 Aralık 1914.

Tanin, nr. 1465, 9 Ekim 1912.

Tasvir-i Efkar, nr. 330, 2 Eylül 1286.

Tasvir-i Efkar, nr. 363, 22 Kânunusani 1286.

Tasvir-i Efkar, nr. 893, 25 Ekim 1913.

Tercüman-ı Hakikat, nr. 6767-1567, 27 Şubat 1900.

Tercüman-ı Hakikat, nr. 10147, 30 Haziran 1905.

Tercüman-ı Hakikat, nr. 10149, 2 Temmuz 1905.

Tercüman-ı Hakikat, nr. 10177, 1 Ağustos 1909.

Tercüman-ı Hakikat, nr. 12490.

Tercüman-ı Hakikat, nr. 12504, 7 Şubat 1916.

Topçu Mecmuası nr. 16, 1926.

The Scotsman, 1 Ekim 1901.

The Scotsman, 8 Ekim 1908.

The Star, 6 Ocak 1864.

The Times, 20 Kasım 1877.

The Times, 21 Kasım 1877.

The Times, 23 Kasım 1877.

\section{Salnameler}

1322 Sene-i Hicriyesine Mahsus Trabzon Vilayeti Salnamesi

Devlet-i Aliye Salnâmesi, (1293)

ilmiye Salnamesi, (İstanbul: Matbaa-i Âmire, 1334)

Rasadhâne-i Âmirenin Salnâmesi, (İstanbul: Rasadhâne İdaresi, 1288)

Salnâme-i Devlet-i Aliye-i Osmaniye, (Dersaadet: Matbaa-i Âmire, 1311)

Salnâme-i Devlet-i Aliye-i Osmaniye 1321 Hicri, (Dersaadet: 1319)

Salnâme-i Devlet-i Aliye-i Osmaniye 1323 Hicri, (Dersaadet: 1321)

Salnâme-i Devlet-i Aliye-i Osmaniye, (Dersaadet: Selanik Matbaası, 1326)

Salnâme-i Devlet-i Aliye-i Osmaniye, (Dersaadet: Selanik Matbaası, 1327)

Salnâme-i Nezaret-i Maarif-i Umumiye, (İstanbul:1319)

Takvim ve Hayriye Salnâmesi, (Dersaadet: Orhaniye Matbaası, 1921)

Takvim-i Sâl, (İstanbul: İbrahim Efendi Matbaası, 1312)

\section{Basılı Eserler ve Makaleler}

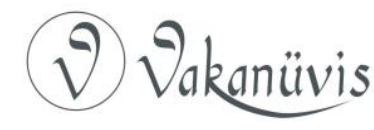


Acun, Hakkı, Osmanlı Imparatorluğu Saat Kuleleri, Atatürk Kültür Merkezi, Ankara 2011.

Ahmet Tevfik, Ziraî Meteoroloji, Cumhuriyet Matbaası, İstanbul 1340.

Atabay, Mithat, "Istanbul'un Hava Koşullarının Ölçülmesi Kurulan Rasathaneler", İstanbul Araştırmaları Yıllığı, 5 (2016), s. 1-14.

Aydüz, Salim. "Osmanlı Astronomi Müesseseleri”. Türkiye Araştırmaları Literatürü Dergisi, 2 /4, s. 411-453.

Biray, Nergis Biray, "Bugün Hava Nasıl Olacak?", Ankara Üniversitesi Dil ve Tarih-Coğrafya Fakültesi Türkoloji Dergisi, 20(2013), s. 1-30.

Coumbary, Dersaadet Rasathâne-i Âmire'nin Cevv-i Havaya Dair Yirmi Senelik Tarassudatı Neticesi, Dersaadet 1304.

Dizer, Muammer, Kandilli Rasathanesi, Kandilli Rasathanesi Yayınları, İstanbul 1973.

Erkan-ı Harbiye Miralayı Muzaffer, Kuva-yı Havaiye Rehberi, Matbaa-i Askeriye, ìstanbul 1926.

Fazıl Nazmi, "Yunan-ı Kadim ve Eski Roma'da Takvim-i Sâl ve Usul-ı Tevarih", Darülfünun Edebiyat Fakültesi Mecmuası, 3-4 (1341), s. 146-161.

FETTAHOĞLU, Kübra, Rasadhane-i Âmire'nin Kuruluşu ve Faaliyetleri, Basılmamış Yüksek Lisans Tezi, İstanbul 2012.

Güner, İbrahim ve Şimşek, Oğuz, "Iğdır'da Halk Takvimi ve Halk Meteorolojisi", Türk Coğrafya Dergisi, 33 (1998), s. 123-135.

Günergun, Feza, "Salih Zeki ve Astronomi: Rasathane-i Amire Müdürlügü̈'nden 1914 Tam Güneş Tutulmasına”, Osmanlı Bilimi Araştırmaları, VII/1 (2005), s. 98-122.

Güngör, Selahattin, Komutanlarımızın Harp Hatıraları, Kanaat Kitabevi, İstanbul 1937.

GÜNTAN, Çağrı, II. Abdülhamit Döneminde Imparatorluk Imajının Kamu Yapıları Aracılığı Ile Osmanlı Kentine Yansıtılması, Basılmamış Yüksek Lisans Tezi, İstanbul 2007.

KAÇAR, Mustafa, Osmanlı Telgraf İ̧̧letmesi, Basılmamış Yüksek Lisans Tezi, İstanbul 1986.

Kadıoğlu, Sevtap, Osmanlı'dan Cumhuriyet'e Meteorolojinin Kurumsallaşması ve Ahmet Tevfik Göymen, Ankara Matbaa, İstanbul 2012.

Karal, Enver Ziya, Osmanlı Tarihi, 9. Cilt, TTK, Ankara 1999.

Nejad, Edhem, "Mekteplerde Alâim-i Cevviye Rasadhaneleri", Sırat-ı Müstakim, 130 (1326), s. 426-428.

Ünver, A. Süheyl, "Tarihimizde İcadiye Tepesi ve Rasadhanesi”, Türkiye Turing ve Otomobil Kurumu Belleteni, 240 (1962), s. 7-8.

Waikman, L, Şarkî Bahr-i Sefid Havalisinde Tazyik-i Nesimî ve Rüzgârlar, Çev. Tevfik Ali, İstanbul 1341.

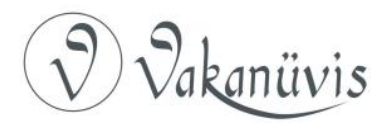


Yeşilyaprak, Hülya, "Kandilli'nin Teleskopları", Türkiye'deki Teleskoplarla Bilim Sempozyumu, s. 57-81. 


\section{EKLER}

Ek 1: London Standard'ın 20 Aralık 1877'de Sunmuş Olduğu Hava Raporu $^{60}$ :

\begin{tabular}{|c|c|c|c|c|c|c|c|}
\hline \multicolumn{8}{|c|}{ Geçen 24 Saatteki Hava Durumu } \\
\hline 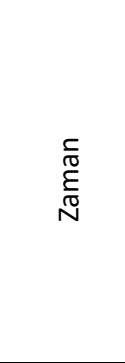 & 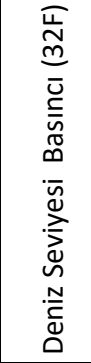 & 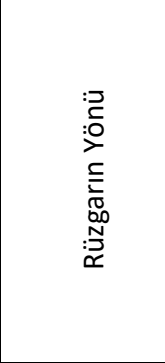 & 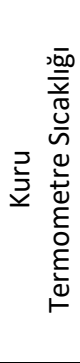 & 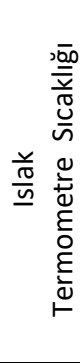 & 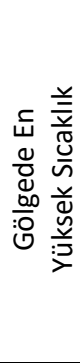 & 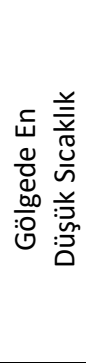 & 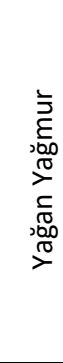 \\
\hline 14 Aralık & 30,41 & Kuzey-Batı & 41 & 40 & 44 & 32 & ..... \\
\hline 15 Aralık & 30,43 & Batı & 46 & 45 & 47 & 31 & ...... \\
\hline 16 Aralık & 30,29 & Kuzey-Batı & 49 & 48 & 50 & 46 & 0,02 \\
\hline 17 Aralık & 30,36 & Kuzey-Batı & 49 & 47 & 49 & 44 & $\ldots .$. \\
\hline 18 Aralık & 30,57 & Kuzey-Doğu & 45 & 42 & 46 & 41 & $\ldots .$. \\
\hline 19 Aralık & 30,66 & Güney-Batı & 41 & 40 & 41 & 30 & ...... \\
\hline
\end{tabular}

Ek 2: Sabah Gazetesi'nin Sunmuş Olduğu Hava Durumları ${ }^{61}$ :

\begin{tabular}{|l|c|c|c|}
\hline \multicolumn{5}{|l|}{ Rasathâne-i Âmire'nin İstanbul'a Ait Hava Durumu } \\
\hline \multicolumn{3}{|l|}{ Cuma } \\
\hline & Perşembe & \multicolumn{2}{c|}{} \\
\hline Hava Basıncı (Milimetre) & Öğle Sonrası & Öğle Öncesi & Ögle Sonrası \\
\hline Hava Sıcaklığı (Santigrat) & 759,5 & 761,2 & 762,6 \\
\hline Nem Oranı & 21 & 21,4 & 24,8 \\
\hline Rüzgârın Hızı (Saniye / Metre) & 90 & 89 & 74 \\
\hline Rüzgârın Yönü & 2 & 0 & 9 \\
\hline $\begin{array}{l}\text { Bulutluluk Durumu (10:Tamamen } \\
\text { Kapalı) }\end{array}$ & Yıldız-Poyraz & Yııdız-Poyraz & Yıldız-Poyraz \\
\hline
\end{tabular}

60 London Standard, 20 Aralık 1877, s. 6.

${ }^{61}$ Sabah, nr. 7885, 2 Eylül 1911, Cumartesi, s. 4; Sabah, nr. 299, 28 Haziran 1890, s. 3. 
Ek 3: Dersaadet Gazetesi'nin Sunmuş Olduğu Hava Durumu²:

\begin{tabular}{|l|c|l|}
\hline \multicolumn{4}{|c|}{ Dün Sabahki Durum } \\
\hline Merkez & Sıcaklık & Yağış \\
\hline Viyana & 15 & Yağmur \\
\hline Petersburg & 16 & Yağmur \\
\hline Odesa & 16 & Yağmur \\
\hline Paris & 18 & \\
\hline Trabzon & 21 & \\
\hline İmir & 22 & \\
\hline Beyrut & 27 & \\
\hline Bağdat & 35 & \\
\hline Basra & 39 & \\
\hline
\end{tabular}

\begin{tabular}{|l|l|}
\hline \multicolumn{2}{|c|}{ Tahvilat-ı Havaiye } \\
\hline Dün Sabahki Sıcaklık & 23,5 \\
\hline Dün Öğle Vakti Sıcaklık & 26 \\
\hline Basınç & 857,5 \\
\hline \multicolumn{2}{|c|}{ Hava açık olup sıcak devam } \\
edecektir.
\end{tabular}

62 Dersaadet, nr. 20, 27 Temmuz 1336, s. 4. 